FEMINISM AND LINGUISTIC THEORY 


\section{FEMINISM AND \\ LINGUISTIC THEORY}

Deborah Cameron

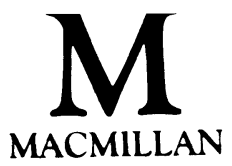




\section{(C) Deborah Cameron 1985}

Softcover reprint of the hardcover 1st edition 1985 978-0-333-37077-3

All rights reserved. No part of this publication may be reproduced or transmitted, in any form or by any means, without permission

First published 1985 by THE MACMILLAN PRESS LTD

London and Basingstoke

Companies and representatives throughout the world

British Library Cataloguing in Publication Data Cameron, Deborah

Feminism and linguistic theory

1. Woman and language

I. Title

$400 \quad$ P120.W6

ISBN 978-0-333-37078-0 ISBN 978-1-349-17727-1 (eBook)

DOI 10.1007/978-1-349-17727-1 


\section{Contents}

Preface: On Demystification vii

1. Introduction: Language and Feminism 1

2. Linguistic Theory: Frameworks and Approaches 9

3. The Politics of Variation: Sex Differences in Language and Linguistics 28

4. False Dichotomies: Grammar and Sexual Polarity 57

5. Making Changes: Can We Decontaminate Sexist Language?

6. Silence, Alienation and Oppression: Feminist Models of Language (I)

7. Feminist Models of Language (II): Semiology and the Gendered Subject

8. Beyond Alienation: An Integrational Approach to Women and Language

9. Conclusion: Feminism and Linguistic Theory: Problems and Practices

Notes

Bibliography

Glossary

Index 


\section{Preface: On Demystification}

As a feminist academic, I am aware of certain obligations and responsibilities. I am conscious, for instance, that many women have been denied the privilege of higher education. By this I certainly don't mean the chance to imbibe 'wisdom' from 'great minds', nor even the opportunity to develop and discuss ideas, which feminists do anyway. I mean the right to financial support, the right to organise your own time, and the right to use the informational, technical, social and recreational facilities of a college or university. In our society these are privileges indeed, and women get less of a share in them than men.

I also realise that many women consider higher education the very reverse of a privilege. They are only too delighted never to have sold their souls and brains to the repressive patriarchal values of academic institutions.

So my responsibilities are these. First, I must be responsive to the needs and concerns of women outside academic life; and secondly I must challenge the practices and values that keep women outside.

Because of these obligations, I have tried to write this book in a particular way, one that I feel embodies feminist principles. That in itself is a challenge to the status quo; and the essence of the challenge lies in my concern to demystify language and linguistics.

Intellectual mystification occurs when a writer, to put herself in a position of authority, denies the reader sufficient resources to understand and dispute what she says. It can be done in a number of ways.

For example, the writer may leave unexplained and taken for granted the conceptual framework she is working in, or may present it as a given rather than something open to question. Or she may depersonalise herself, hiding behind the spurious authority of an 'objective commentator' by not making it clear 
where she stands, politically and intellectually, in relation to the ideas she discusses.

In this book, therefore, I have tried to spell out even the most basic assumptions behind the theories I deal with, and to provide enough background to suggest how they may be called into question themselves. I have been at pains to make clear what my own opinions are, and to present the opinions of others scrupulously. To do this I have used a lot of quotation - which allows my subjects to some extent to speak for themselves - and it is important that the reader scrutinise that quotation carefully.

Another important source of mystification in academic writings is the language used: indeed, it could be said that mystification BY language and mystification OF language are the joint subjects of this book. Writers may prevent readers from dealing with their ideas as anything more than gibberish, or as anything less than received truth, by writing in a way that is incomprehensible. Alternatively, they may be so vague that no clear line of thought emerges. Then, if they are criticised, it is easy for them to claim they have been misinterpreted.

In this book I have attempted a relatively simple style. An important addition to the text is the glossary of linguistic and other technical terms, which the reader should refer to whenever necessary for a concise account of what I mean by using various unfamiliar words.

I have avoided language that conceals the presence of the writer and the process of writing. The word $I$ appears frequently, and at many points I indicate exactly what argument I am trying to put forward. The aim here is to give the reader every opportunity of saying to herself, 'hold on a minute, that doesn't follow', or 'but what about x?' or 'I can't accept that'. In other words, the reader is encouraged to be an active maker of her own ideas in relation to this book, and not simply a passive consumer of other people's.

I have also avoided offensive and sexist language, replacing it either with 'neutral' terminology or, more often, with terms that draw attention to the existence of women. Most sex-indefinite and generic referents in this book will be she and her. If there are any men reading who feel uneasy about being excluded, or not addressed, they may care to consider that women get this feeling within minutes of opening the vast majority of books, and to reflect on the effect it has. 
Finally, I acknowledge that I did not write this book unaided: many groups and individuals contributed to it in different ways. Some of them participated in discussions of language and sex; some showed me their work, or shared information and experiences they thought might be useful; some read and commented on the typescript; some gave me encouragement and support while I was writing it. One particular group, my students, helped me by obliging me to concentrate on the basics of linguistic theory and to work out the best ways of explaining them.

I would like to thank the following in particular: participants in the first WAVAW conference workshop on language and violence; members of Balliol College Women's Group, Pembroke College Women's Group, Oxford University Women in Politics seminar and Oxford Rape Crisis Group; Kate Cameron, Tony Crowley, Liz Frazer, Ian Griffiths, Roy Harris, Caroline Henton, Rebecca Hiscock, Radhika Holmström, Bob Hoyle, Helen Lawrence, Toril Moi, Peter Mühlhäusler, M. Nawaz, Elizabeth Powell-Jones and Marni Stanley.

D.C. 